\title{
O PASSADO ANULADO: OS REFLEXOS DA INADEQUADA JUSTIÇA TRANSICIONAL PARA A DEMOCRACIA BRASILEIRA
}

\author{
ANNULLED PAST: THE INADEQUATE TRANSITIONAL JUSTICE \\ REFLEXES ON BRAZILIAN DEMOCRACY
}

\author{
Carla Dóro de Oliveira' \\ Doglas Cesar Lucas²
}

\begin{abstract}
RESUMO: O trabalho busca analisar o processo transicional brasileiro pelo estudo das medidas adotadas pelo Estado durante a redemocratizaçăo. A partir disso, buscou-se reconhecer os aspectos positivos e negativos do processo justransicional, identificando de que forma sua incompletude influencia na democracia e na persistência de um cenário de violência no país. Na metodologia utilizou-se pesquisa bibliográfica numa abordagem qualitativa. Os resultados do trabalho apontam que medidas adotadas pelo Brasil, apesar de relevantes, săo insuficientes para a consolidaçăo de uma cultura democrática e de respeito aos direitos humanos no país, impondo-se, assim, a implementaçấo da justiça transicional em todos os seus aspectos.
\end{abstract}

Palavras-chave: Democracia. Direitos Humanos. Ditadura. Justiça de Transiçāo. Memória.

ABSTRACT: This work aims to analyze the Brazilian transitional process by studying the measures adopted by the Brazilian government during its democratization. From this, this paper tried to recognize the positives and negatives aspects of this process, identifying the points that deserve more attention. In the methodology, it was used bibliographic research, in a qualitative approach. Our results indicate that the measures taken until now, although relevant, are insufficient for the consolidation of democracy in our country. In this context, it is necessary to implement the transitional justice in all its aspects.

Keywords: Democracy. Dictatorship. Human Rights. Memory. Transitional Justice.

Mestranda em Direitos Humanos pela Universidade Regional do Noroeste do Estado do Rio Grande do Sul - UNIJUÍ. Bolsista da CAPES. carladorodeoliveira@gmail.com

2 Pós-doutor em Direito pela Università degli Studi Roma Tre, Itália. Doutor em Direito pela UNISINOS e Mestre em Direito pela UFSC. Professor nos cursos de Graduaçăo e de Mestrado em Direito da UNIJUÍ. Professor no Curso de Graduaçáo em Direito do Instituto Cenecista de Ensino Superior de Santo Ângelo IESA. Professor visitante do mestrado em direito da URI - Santo Ângelo. Avaliador MEC/INEP. Consulto Ad Hoc da Capes. Líder do Grupo de Pesquisa no CNPQ Fundamentos e concretizaçâo dos Direitos Humanos. doglasl@unijui.edu.br 


\section{CONSIDERAÇÕES INICIAIS}

Há soldados armados / Amados ou nâo / Quase todos perdidos / De armas na mâo / Nos quartéis lhes ensinam / Uma antiga liçâo / De morrer pela pátria / E viver sem razāo.

Em setembro de 1968, Geraldo Vandré eternizou no coraçáo dos brasileiros as angústias vividas nos anos de chumbo. No auge da repressấo, num festival de cançăo no Maracanázinho, Rio de Janeiro, o cantor fez surgir um hino contra a ditadura. Tratavase da música "Para năo dizer que náo falei das flores" que, embora năo tenha ganhado o festival, ganhou o coraçăo dos ouvintes.

Dois anos antes disso tinha início a ditadura civil-militar brasileira que, durante mais de duas décadas, censurou, perseguiu, torturou e assassinou brasileiros e estrangeiros, levando o país ao caos político e econômico. Apenas em 1989 - vinte e nove anos depois da eleiçấo de Jânio Quadros - os brasileiros puderam escolher seu presidente por meio do voto direto. No entanto, embora hoje nossa democracia formal possa ser considerada forte, vivemos tempos sombrios. A desigualdade social, a violaçâo cotidiana dos direitos fundamentais dos cidadăos e a violência já năo mais nos chocam. Assistimos incrédulos aos acontecimentos que abalam nosso país. Por isso, surge o questionamento: a redemocratizaçáo do país efetivamente democratizou as instituiçôes públicas, trazendo melhoras no tratamento das questóes envolvendo os direitos humanos?

Transcorridos mais de cinquenta anos desde o golpe que instaurou a ditadura militar brasileira o Brasil ainda vive situaçôes de graves violaçóes de direitos humanos. O processo transicional brasileiro, embora tenha avançado significativamente nos últimos anos, ainda se encontra em estado de abandono e, em comparaçăo com os países vizinhos, estamos, sob muitos aspectos, atrasados e em débito com a nossa populaçăo.

Com isso em mente, o presente trabalho tem por objeto o estudo da justiça de transiçấo, em seus variados aspectos, a fim de entender quais as medidas adotadas pelo Brasil a fim de superar a ditadura civil-militar, bem como os impactos dessas medidas na construçấo de uma cultura democrática e de respeito aos direitos humanos. Buscamos, a partir desse estudo, entender como o Brasil está lidando um capítulo tăo traumático da sua história e quais os efeitos do regime ditatorial na democracia brasileira hoje.

\section{ENQUANTO O HOMEM CHEGA À LUA, NO BRASIL, A DITADURA NOS APRESENTA O PORÃO}

Imaginemos um país assolado por uma crise econômica persistente que mantinha a inflaçăo em altos índices, assombrado pelo fantasma do comunismo num mundo polarizado pelo contexto da Guerra Fria, chefiado por um presidente que flertava perigosamente com a esquerda. Para completar o quadro, uma classe média conservadora e carola que, junto da Igreja Católica, exigia o extermínio do materialismo e do ateísmo da ideologia marxista. Pois foi nesse cenário que nasceu o golpe que instituiu a ditadura civil-militar no Brasil em 1964. 
A década de 1960 trouxe consigo uma explosăo de novidades ao redor do mundo: o programa espacial norte-americano lançou o homem à lua; a pílula anticoncepcional prometia a libertaçấo feminina; surgiu a TV em cores; o rock mudava o cenário musical e um novo grupo ganhava notoriedade, eram The Beatles.

No Brasil, o presidente Jânio Quadros permaneceu por apenas oito meses no poder, renunciando em agosto de 1961. Seu vice, Joăo Goulart, o Jango, causava arrepios na direita brasileira. Prometendo reformas de base, só conseguiu assumir a presidência após um acordo pelo qual o parlamentarismo foi instituído no país, a fim de refrear a atuaçăo do novo chefe do Executivo. Apenas em 1963, Jango venceu o parlamentarismo e assumiu as rédeas do país. Em dezembro daquele ano o Brasil atingiu a maior inflaçâo de sua história $(79,9 \%)$ e teve o menor crescimento do Produto Interno Bruto $(0,6 \%)$ desde o início dos cálculos (GASPARI, 2002).

Os rumores eram de que a esquerda, aliada a Jango, planejava um golpe para instituir o comunismo no país. A direita, no entanto, apoiada estrategicamente pela embaixada norte-americana no Brasil, na pessoa do embaixador Lincoln Gordon, alegava atuar de forma "preventiva". Se necessário, dariam o golpe para evitar outro golpe (GASPARI, op. cit.).

Apesar de o Partido Comunista Brasileiro (PCB), que reunia toda a esquerda nacional na época, afirmar que náo pegaria em armas para lutar pelo socialismo no país, em março de 1964 tudo indicava que o golpe viria. Se năo de esquerda, de direita (GASPARI, op. cit.).

No dia 13, Jango discursou no Comício da Central, ocasiăo na qual criticou o que chamou de "indústria do anticomunismo", posicionando-se, ainda, contrariamente ao uso de símbolos religiosos na campanha contra o seu programa de reformas de base (CODATO; OLIVEIRA, 2004). A classe média năo se acovardou, respondendo com a Marcha da Família com Deus pela Liberdade, realizada no dia 19 de março em Săo Paulo. Sob a organizaçăo da Uniâo Cívica Feminina (UCF-SP), da Igreja Católica e do IPES, ${ }^{3}$ a marcha reuniu mais de 500 mil pessoas (10\% da populaçăo da cidade na época). ${ }^{4}$ Esse evento proporcionou às Forças Armadas um requisito fundamental para a ditadura brasileira: o apoio da populaçăo.

Turbulento como foi, março tinha mais a oferecer. No dia 30, Jango fez seu último discurso na presidência. Na ocasiăo, disse: "Năo queremos o Congresso fechado. [...] queremos o Congresso aberto. Queremos apenas que os congressistas sejam sensíveis às mínimas reivindicaçōes populares" (GASPARI, 2002, p. 65). Foi a gota d'água. Jango acordou deposto.

O golpe teve início com o general Olympio Mourăo que, no entanto, năo desempenhou papel importante durante o regime que ajudou a instaurar. Jango, pressentindo o perigo, voou do Rio para Brasília no dia 1o de abril, e de lá para o Rio Grande do Sul, onde Brizola buscava oferecer resistência ao golpe, mas o apoio năo veio (GASPARI, op. cit.).

\footnotetext{
3 Instituto de Pesquisas e Estudos Sociais, fundado em 1961 e composto por empresários e militares.

4 Onúmero de participantes náo é exato, variando de trezentos mil a setecentos mil, conforme o documento consultado.
} 
A 9 de abril, baixou-se o primeiro Ato Institucional de que se teria notícias, cassando mandatos e ampliando os poderes presidenciais. O AI-1 esclarecia à naçăo que a "revoluçăo" que estava em andamento no país se dava no interesse do povo, visando "drenar o bolsâo comunista". No dia 11 de abril Castello Branco tornou-se presidente da República.

Castello Branco desejava ser o único presidente durante a ditadura civil-militar brasileira, devolvendo a democracia ao país em 1966 por meio de eleiçôes diretas (CHAGAS, 1985), mas suas esperanças náo passavam de utopia. Com o decorrer do tempo, os atos institucionais se mostraram insuficientes e, em 1967, uma nova Constituiçâo foi outorgada.

Assim, em outubro de 1965 baixa-se o Ato Institucional no 2 (AI-2), instituindo um novo ciclo de cassaçôes de mandatos parlamentares e extinguindo os partidos políticos a fim de enfraquecer a oposiçăo (FAUSTO, 2001). O AI-2, para mais, transferiu para a Justiça Militar a competência para o julgamento dos crimes políticos. No ano de 1966, realizaram-se eleiçôes indiretas para a Presidência da República. Costa e Silva, entâo Ministro da Guerra, foi o sucessor "natural" de Castello, tomando posse no cargo em março de 1967 (GASPARI, 2002).

$\mathrm{O}$ ano seguinte foi turbulento. Dentre vários acontecimentos, em setembro, um evento aparentemente insignificante serviu para legitimar o AI-5. O entăo deputado, Marcio Moreira Alves, pronunciou-se no Congresso num horário "no qual os parlamentares ocupam a tribuna para tratar de assuntos irrelevantes" (GASPARI, op. cit., p. 314). Foi um discurso sem repercussão, divulgado apenas em pequena nota na Folha de Sâo Paulo. O ministro Lyra Tavares, no entanto, criou um monstro a partir dessa manifestaçăo (GASPARI, op. cit.).

Para esquentar os ânimos, a esquerda começava a promover atentados para chamar a atençấo da mídia e mandar um aviso para os militares: nâo aceitariam a ditadura sem lutar. Os militares, por sua vez, também estavam insatisfeitos. Com seus baixos salários, tinham de suportar todo o ódio da populaçấo e da oposiçăo contra o regime ditatorial. "Os dois lados queriam provar que estourara uma revolução no Brasil, mas como ela nâo existia, contentavam-se em proclamar a existência do processo a que chamavam de 'guerra revolucionária'" (GASPARI, op. cit., p. 329). Disso tudo, percebese que o cenário político do país em 1968 era uma grande farsa, um teatro muito bem montando no qual a esquerda fingia atacar o regime militar e o governo fingia acreditar que a esquerda era, de fato, uma ameaça. Fingiram tâo bem que acreditaram no próprio embuste. 0 resultado dessa encenaçâo foi o AI-5.

Assim, a 13 de dezembro veio o AI-5, "o golpe dentro do golpe", fechando o Congresso Nacional. A partir de entăo se tornou comum a realizaçăo de "escuta telefônica, violaçăo de correspondência e denúncias por informantes" (SKIDMORE, 2000, p. 232). Para mais, "estabeleceu-se na prática a censura aos meios de comunicaçăo; a tortura passou a fazer parte integrante dos métodos de governo" (FAUSTO, 2001, p. 480). As disposiçôes mais gravosas do ato referem-se à suspensâo da garantia de habeas corpus nos casos de crimes políticos, contra a segurança nacional, a ordem econômica e social e a economia popular.

No ano seguinte, as açôes dos grupos de luta armada se intensificaram e incluíram assaltos a bancos e sequestro de autoridades. A ideia era arrecadar dinheiro para as 
açōes; demonstrar que as cidades capitalistas năo eram invencíveis e, finalmente, negociar a troca das importantes personalidades sequestradas por presos políticos (SKIDMORE, 2000).

Se, inicialmente, os grupos armados assustaram o governo, eles foram rapidamente silenciados ante a forte repressăo estatal e, em meados de 1970, já năo tinham mais força para resistir. Isso porque, dados indicam que o número de militantes envolvidos no terrorismo girava em torno de oitocentos e mesmo nas estimativas mais pessimistas, como a do coronel Ustra, nâo passava 1650 pessoas (GASPARI, op. cit.). Assim, recorrendo à tortura e outras práticas criminosas, o Exército dizimou tais grupos com incrível rapidez (SKIDMORE, op. cit.).

Vários foram os motivos que levaram os militares a, lentamente, deixar o governo. Nessa lógica, cumpre dar espaço à participação das mulheres no cenário político nacional nas décadas de 1960 e 1970. Isso porque é muito comum nos depararmos com histórias das militantes de esquerda que lutaram contra a repressăo. Embora essas sejam importantes, buscamos, por meio desse trabalho, trazer uma nova perspectiva. Nossa abordagem parte da atuaçâo da mulher no apoio à deposiçăo do Jango, que deu início à ditadura, e percorre o caminho trilhado por elas até chegarem à oposiçâo pacífica ao regime ditatorial, quando as mâes e esposas dos presos políticos e exilados passaram a exigir o retorno da democracia.

Os grupos femininos existiam nas principais cidades brasileiras. No Rio de Janeiro, a Campanha da Mulher pela Democracia (CAMDE) surgiu em junho de 1962. Em Sáo Paulo, a Uniāo Cívica Feminina (UCF-SP) surgiu no mesmo ano, tendo sido registrada em março de 1963, ano em que também foi fundada a Liga da Mulher Democrata (LIMDE), em Belo Horizonte (SESTINI, 2007). No Rio Grande do Sul, em 1964 foi organizada a Açầo Democrática Feminina Gaúcha (ADFG) (CHAVES, 2014), dentre outras espalhadas pelo país.

De acordo com Janaína Martins Cordeiro (2007), as entidades femininas fundadas na década de 1960 foram essenciais para a formaçăo da opiniăo pública a respeito da importância do "resguardo" das liberdades democráticas em funçâo da ameaça comunista que supostamente rondava o país.

Esses grupos femininos, reunidos para lutar pela família, pela Pátria e pela democracia, eram compostos por mulheres que - diferentemente das militantes de esquerda - náo romperam com o estereótipo feminino da época. Apesar assumirem um local no espaço público, sustentavam um discurso conservador, pautado no catolicismo, reforçando a ideia de que atuavam na condiçăo de mâes, de esposas, de donas-de-casa com a finalidade de resguardar os "valores da família brasileira". Sua participaçấo nos grupos femininos era encarada como uma luta "apartidária" e até mesmo "apolítica". Tais mulheres, assumindo o papel socialmente imposto, aceitavam a submissăo de seus maridos, ficando até mesmo agradecidas quando eles lhes "permitiam" participar dessa importante luta "pela democracia" (CORDEIRO, 2008).

Deve-se observar que, embora as mulheres tenham apoiado o golpe, em 1964 - em sua maioria mulheres católicas conservadoras, măes e esposas - e após o golpe as mulheres tenham contribuído na luta da esquerda contra a ditadura - geralmente se observa a participaçăo de mulheres jovens, economicamente ativas e/ou estudantes - nâo foi apenas dessas duas formas que se deu a participaçăo das mulheres no cenário político 
do Brasil ditatorial. Muitas mulheres, especialmente máes, esposas, irmăs e filhas de presos políticos, atuaram na resistência pacífica ao regime, por meio de manifestaçóes e protestos, a exemplo do Movimento Feminino pela Anistia (RIDENTI, 1990).

Até porque, se a elite da sociedade brasileira sempre gozou da complacência dos órgáos estatais quando da apuraçáo e puniçấo de seus crimes, tudo mudou durante a ditadura. Os órgăos da repressăo nâo tiveram complacência com os "filhos da elite". Conforme Skidmore (op. cit., p. 246), nos porôes da ditadura "elite e năo-elite tinham o mesmo tratamento". E foi graças a isso que, aos poucos, Igreja, OAB e as famílias de classe média passaram a lutar contra o governo militar e as violaçóes aos direitos humanos.

Assim, diferentes grupos passaram a atuar na luta em prol da anistia. De acordo com Jessie Jane Vieira de Sousa (2011), o Movimento Feminino pela Anistia (MFA) foi um dos precursores na luta pela anistia. O MFA, surgido em 1975 sob a liderança de Terezinha Zerbini, objetivava mobilizar a opiniăo pública em defesa dos presos políticos e pelo retorno dos exilados, a partir de uma anistia ampla e geral. No entanto, essa posiçăo de protagonismo das mulheres na resistência ao regime năo encontra significativo espaço nas narrativas históricas.

Apesar de o projeto de anistia lançado pelo Executivo ter saído vitorioso, a mobilizaçăo da populaçấo por meio das organizaçóes civis como o MFA náo foi em vấo, pois o projeto apoiado pelo governo venceu por uma pequena margem de votos graças aos votos dos "senadores biônicos", que eram indicados pelo governo ditatorial e que compunham um terço do Senado (GONÇALVES, 2009). Ademais, a uniăo da sociedade em torno de uma mesma bandeira demonstrou a força da populaçấo e serviu para acelerar a redemocratizaçăo do país.

Além disso, a Igreja e a OAB também foram importantes na reabertura do regime. Conforme o Projeto Brasil: nunca mais (1985), năo se pode negar que a Igreja Católica foi importante apoiadora da intervençăo militar na década de 1960. No entanto, isso começou a mudar em 1968 por inúmeras razóes, dentre as quais podemos citar a repressăo policial excessiva, a decretaçáo do AI-5 e o início da formaçăo das Comunidades Eclesiais de Base.

A Ordem dos Advogados do Brasil (OAB) também foi favorável à deposiçăo do entâo presidente Joáo Goulart e à intervençăo militar, tendo levado considerável tempo para mudar de conduta. Ainda assim, reagiu (SKIDMORE, op. cit.).

A mudança se deu, igualmente, em decorrência do cenário político mundial. Aos poucos, as organizaçôes de proteçâo e defesa dos direitos humanos voltaram sua atençấo às atrocidades cometidas pelos agentes do estado no Brasil e até o Vaticano passou a condenar os maus-tratos aos quais os presos políticos eram submetidos. Paralelamente, a OAB e os advogados dos presos políticos passaram a lutar contra as ilegalidades cometidas pelas forças policiais e pelos órgăos da justiça, buscando assegurar os direitos dos seus clientes (SKIDMORE, op. cit.).

O que năo se pode deixar de lado é que o trabalho da Igreja Católica, da Ordem dos Advogados do Brasil e da sociedade civil - em prol da bandeira da anistia -, foram fundamentais para a abertura do regime ditatorial, uma vez que deixaram claro às autoridades militares que o povo, como um todo, desejava o retorno da 
democracia e das liberdades civis e nâo mais toleraria a continuidade das Forças Armadas no poder.

\section{A JUSTIÇA DE TRANSIÇÃO NO BRASIL: UM PROCESSO INACABADO}

A justiça de transiçāo se refere às medidas adotadas por um país visando à construçâo de uma cultura democrática após um período de restriçâo de direitos individuais. Nesse sentido, Paul Van Zyl (2011, p. 47) esclarece: "pode-se definir a justiça transicional como o esforço para a construçăo da paz sustentável após um período de conflito, violência em massa ou violaçấo sistemática dos direitos humanos".

Para que se torne completo, o processo transicional deve passar por quatro etapas distintas: "(i) a reparaçăo, (ii) o fornecimento da verdade e a construçăo da memória, (iii) a regularizaçấo da justiça e o restabelecimento da igualdade perante à lei e (iv) a reforma das instituiçōes perpetradoras de violaçôes contra os direitos humanos" (ABRÂO; TORELLY, 2011, p. 215). Cada qual desempenha relevante e indispensável papel na construçăo de uma democracia fundada em bases seguras, servindo para devolver às vítimas do regime um espaço digno para que possam reconstruir suas vidas.

A primeira dimensâo da justiça transicional, a reparaçăo, diz respeito tanto à indenizaçăo pelos danos materiais causados às vítimas das violaçôes de direitos humanos, quanto à assistência psicológica e medidas de cunho simbólico, tais como memoriais e monumentos (VAN ZYL, 2011). Um aspecto deve ser trabalhado paralelamente ao outro, conciliando-se a reparaçăo pecuniária com a moral. No entanto, no Brasil houve, até pouco tempo, inegável preferência pelo modelo pecuniário de reparaçaáo o que acarreta um "menosprezo pelos avanços transicionais arduamente conquistados até aqui e o desrespeito em relaçấo aos perseguidos políticos que passam a ser vistos, [...] como 'caçadores de tesouros' às custas do dinheiro público" (BAGGIO, 2011, p. 254).

Quanto ao aspecto reparatório, a justiça de transiçáo tem como desafio permitir o reconhecimento das vítimas da repressâo, do seu modo de vida e de suas convicçôes, uma vez que, desse modo, estaria permitindo "aos sujeitos outrora desrespeitados a (re)construçăo de uma imagem positiva de si mesmos" (BAGGIO, 2011, p. 258). Dita circunstância se faz crucial em face de um regime que classificou como "terroristas" aqueles que se opuseram ao Governo, os quais, em larga maioria - segundo dados da obra Brasil: Nunca Mais5 - foram presos por crimes como militância em organizaçâo partidária proibida e que, até hoje, sâo vistos por parcela da populaçáo brasileira como criminosos.

Esse quadro tem apresentado melhoras, principalmente após a aprovaçăo da Lei n. ${ }^{\circ}$ 10.559/2002, também chamada de nova Lei de Anistia. Regulamentando o artigo oitavo do Ato das Disposiçóes Constitucionais Transitórias (ADCT), referido diploma legal estabeleceu outras medidas de reparaçāo, além da pecuniária, às vítimas do regime ditatorial e instituiu a Comissâo de Anistia no âmbito do Ministério da Justiça, a partir do qual foram implantadas as Caravanas da Anistia.

De acordo com a obra citada, relativamente ao tipo de acusaçăo a que eram acusados os réus, em primeiro lugar estava a militância em organizaçáo partidária proibida (4.935 casos), em segundo lugar e somente com 1.464 casos aparecia a acusaçăo de participaçăo em açâo violenta ou armada. 
Por meio desse projeto, a Comissáo de Anistia se deslocou pelos mais diversos Estados brasileiros atuando em espaços públicos e comunitários na concessâo de anistias (SILVA FILHO, 2015). O trabalho dessas Caravanas da Anistia foi fundamental para a reconstruçấo da memória e da verdade, mas, principalmente, para a valorizaçăo da vítima. A partir das Caravanas o Estado vence a barreira da "amnésia" imposta pela Lei de Anistia de 1979 e admite, finalmente, seus erros. Outro aspecto que torna ainda mais significativo o trabalho das Caravanas da Anistia é o fato de que, durante as sessôes, o anistiando tem a oportunidade de dar seu testemunho sobre os horrores vividos durante a repressăo.

Medidas como essa dăo força ao processo transicional no país, credibilizam a imagem do anistiado político e, fator relevante, quebram o silêncio imposto pela Lei de Anistia, trazendo ao debate a questâo das violaçôes aos direitos humanos cometidas durante a ditadura. Aliás, um modelo reparatório que vai além da reparaçâo pecuniária ajuda a desconstruir a imagem pejorativa dos anistiados.

Um importante estudo analisou os números da Base de Dados da Justiça de Transiçâo (TJDB) e demonstrou que as anistias năo desempenham um papel de todo negativo na justiça transicional desde que combinadas com outras medidas. Que, ademais, a adoçâo isolada das Comissóes da Verdade pode gerar resultados contraproducentes, e que o "seu sucesso depende da combinaçâo das comissóes de verdade com os julgamentos e as anistias" (OLSEN; PAYNE; REITER, 2011, p. 561).

Tais dados reforçam a ideia de que uma justiça de transiçăo lastreada apenas em um sistema reparatório que privilegia a reparaçăo pecuniária e em Comissōes da Verdade - tardiamente instauradas - nâo é suficiente para o avanço dos direitos humanos e o fortalecimento da democracia.

Isso significa que "as anistias poderâo vir antes e serem depois afastadas para que ocorram os julgamentos (como no caso argentino), ou que as anistias convivam com a realizaçăo de alguns julgamentos (como no caso chileno e uruguaio)" (SILVA FILHO, 2015, p. 66). Logo, frisa-se que em dado momento histórico, as anistias podem surgir como a única forma de um governo ditatorial "deixar" o poder. Ademais, que isso nâo pode servir de obstáculo para que essas anistias náo sejam nunca contestadas. Para além, que nem sempre uma lei de anistia precisa ser revogada ou anulada para que a responsabilizaçăo dos agentes públicos que cometeram crimes de lesa-humanidade possa acontecer. Inadmissível é a absoluta negativa, por parte do Estado, dessa dimensăo da justiça transicional.

Quanto aos julgamentos, Van Zyl (2011, p. 49-50) esclarece que eles "podem servir para evitar futuros crimes, dar consolo às vítimas, pensar um novo grupo de normas e dar impulso ao processo de reformar as instituiçôes governamentais, agregando-lhes confiança". O que se deve considerar é que a responsabilizaçăo dos agentes repressores é somente uma das dimensôes da justiça transicional e nâo pode, de modo algum, ser encarada como o aspecto mais relevante, devendo vir aliada dos demais âmbitos do processo transicional.

Igualmente, a estagnaçâo das instituiçôes públicas desde a ditadura civil-militar contribui para a continuidade da violaçáo dos direitos individuais. O que se nota no caso brasileiro é que, até hoje, o Poder Judiciário é conservador, o Exército brasileiro ainda năo reconhece a violaçăo sistemática aos direitos humanos durante o regime 
militar e, por fim, a violência permanece sendo o modus operandi das instituiçóes de Segurança Pública no país.

Para demonstrar os efeitos da falta da reforma das instituiçóes públicas no Brasil, imperioso apresentar os dados colhidos pela organizaçâo nâo governamental Anistia Internacional (AI) nos Informes 2014/2015 sobre "O estado dos direitos humanos no mundo". Na pesquisa, a AI traz informaçôes relativas à violaçăo dos direitos humanos nos mais diversos países onde atua. $\mathrm{O}$ informe é dividido por país, sendo que, logo na introduçâo relativa ao Brasil, registra-se que "prosseguiram as denúncias de graves violaçōes dos direitos humanos, como os homicídios cometidos pela polícia e a tortura ou outros maus-tratos de pessoas detidas" (ANISTIA INTERNACIONAL, 2015, p. 72). Segundo o relatório, nas manifestaçóes ocorridas no ano de 2013, "a Polícia Militar (PM) recorreu com frequência à força excessiva e desnecessária para dispersar manifestantes" (ANISTIA INTERNACIONAL, 2015, p. 73).

Isso ajuda a demonstrar que a impunidade e a falta de uma reforma nas instituiçôes públicas brasileiras após a ditadura contribuem para uma cultura de violência em nosso país. Os órgáos da segurança pública, em vez de fazer cessar a violência com que tratavam os presos políticos, apenas mudaram de foco. Agora, o "inimigo estatal" é o pobre, o negro e o insubordinado. Portanto, a falta de uma transiçăo adequada "se reflete na continuidade da extrema violência empregada pelas forças de segurança pública no país, e em especial da tortura como método de investigação criminal" (SILVA FILHO, 2011, p. 282).

Como já foi dito, a justiça de transiçăo se faz de diferentes aspectos e é quando essas dimensōes sâo trabalhadas em conjunto que se aumentam as chances de obtençâo de avanços significativos na valorizaçâo dos direitos humanos e no fortalecimento da democracia. Nesse sentido, uma transiçấo inacabada "contribui para que a democracia náo se desenvolva, para que ela fique isolada em um discurso democrático ao qual corresponde, em verdade, uma prática autoritária" (SILVA FILHO, 2011, pp. 282-283).

\section{O DESAPARECIMENTO FORÇADO DE ONTEM É A BALA PERDIDA DE HOJE: POR QUE A DEMOCRACIA BRASILEIRA NÃO SAI DO DISCURSO?}

Nas palavras de Alain Touraine (1996, p. 252) "a ausência de regime autoritário năo é democracia". Isso porque a simples mudança nas regras do jogo nem sempre transforma, de fato, a forma como se joga. Embora sejamos herdeiros das promessas da modernidade e tenhamos nos comprometido na luta por igualdade e justiça, hoje acumulamos um grande espólio de dívidas. Nessa senda, para Touraine (op. cit., p. 247),

A aboliçăo do monopólio militar e a instauraçâo de eleiçôes livres năo justificam, por si só, que se fale em democracia. As desigualdades sociais aumentam; os direitos do homem sáo, muitas vezes, violados; e falta quase sempre, na maior parte dos países do continente, a consciência de cidadania.

A realidade social brasileira náo dá espaço ao desenvolvimento de grande parte da populaçăo, que passa a viver à margem da sociedade, excluída, ou, o que é pior, esquecida. Nessa lógica, o direito náo pacifica, apenas estimula a violência, e a delinquência aumenta a cada dia, pois surge como uma forma de tornar visíveis os invisíveis. 
Por isso, afirma Touraine (op. cit., p. 248), "na América Latina, năo haverá democracia ou desenvolvimento sem uma luta ativa contra as desigualdades que crescem a cada dia com a inflaçăo". No Brasil, conforme Streck e Morais (2010, p. 86), "os 20\% mais ricos concentram 32 vezes mais renda do que os $20 \%$ mais pobres. Cerca de $40 \%$ das famílias brasileiras vivem com renda anual inferior a US\$ 1,5 mil". Como acreditar que, nesse cenário, podemos falar em igualdade e em exercício da cidadania? Para mais, vivemos aquilo que Paulo Sérgio Pinheiro (1997) chama de "autoritarismo socialmente implantado", que pode ser notado nos "microdespotismos" da vida diária, manifestados pelo racismo, o machismo e o elitismo.

Nesse contexto, a classe média vive uma paranoia: o fantasma da violência lhe assusta, embora seja ela a populaçăo menos afetada por essa violência (TOURAINE, 1996). Isso porque, conforme Pinheiro (1997, p. 44), “o principal alvo da arbitrariedade policial sâo os mais vulneráveis e indefesos da sociedade brasileira: o pobre, o trabalhador rural e sindicalistas, grupos minoritários, crianças e adolescentes abandonados, muitos vivendo nas ruas". Essa violência nâo atinge, portanto, as classes mais abastadas. A violência "dos marginais", por sua vez, acaba ficando restrita às áreas mais pobres, às favelas, aos guetos. Apenas um percentual reduzido atinge o "restante" da populaçấo.

Isso tudo reforça a ideia de que a simples democratizaçăo "formal", a promulgaçăo de uma nova Constituiçăo e a realizaçăo de eleiçóes diretas, embora sejam importantes, săo insuficientes para que se possa indicar que uma democracia está, de fato, consolidada. "A democratizaçâo impôe uma intervençâo política, uma gestâo negociada das mudanças econômicas e sociais e, sobretudo, uma vontade firme de dar a prioridade à luta contra as desigualdades que destroem a sociedade nacional" (TOURAINE, 1996, p. 249).

Conforme Zaverucha (2010), uma democracia pode ser considerada consolidada quando é tăo legítima e profunda que a probabilidade de ser golpeada é muito pequena. No Brasil, do contrário, ameaças de golpes sâo ouvidas a todo o momento. Nesse cenário, o Exército mantém sua posiçăo de poder e prestígio, desempenhando um papel de superioridade em relaçấo às polícias civil e militar, o que contribui para que a busca por segurança nacional prevaleça sobre a segurança pública, incentivando as forças de segurança a aturem sob a lógica do "inimigo interno".

Desde a redemocratizaçâo tivemos quatro presidentes eleitos pelo voto popular: Fernando Collor de Mello, Fernando Henrique Cardoso, Luis Inácio Lula da Silva e Dilma Rousseff. Desses quatro, dois năo completaram o seu mandato, tendo sofrido impeachment. Longe de buscar compreender os méritos do processo de impedimento dos presidentes Collor e Dilma, fica evidente de que algo anda fora dos eixos em nossa democracia.

Esse quadro vem a ressaltar a falta de uma tradiçăo democrática em nosso país: náo sabemos como praticar a democracia. Escolhemos nossos presidentes como se escolhêssemos um "herói", um "salvador da pátria" e, uma vez acabadas as eleiçôes, esquecemo-nos de seguir participando da política nacional. Somos uma descriçâo perfeita daquilo que O'Donnell (1991) chama de democracia delegativa. Quando o país segue rumos inesperados, entăo, lamentamos a falta de um "governo forte", de um presidente que tenha "pulso firme". 
Sob essa ótica, reportamo-nos à obra de François Ost (1999), O tempo do direito, na qual o autor analisa o tempo enquanto instituiçáo social, e o direito enquanto agente instituinte do social. De acordo com o autor, o direito institui o próprio tempo, servido como um "guardiăo da memória". Para que seja, de fato, agente instituinte do social, o direito precisa trabalhar pensando em um tempo metamórfico, que concilie memória e esquecimento, perdăo e requestionamento. Sem esses quatro aspectos, năo há como se construir um futuro viável.

Desse modo, tanto a memória quanto o esquecimento possuem duas faces, uma positiva e outra negativa. Nesse sentido, o caminho entre memória e promessa passa necessariamente pelo perdáo e pelo esquecimento. No entanto, há variados tipos de esquecimento: o esquecimento-falsário, que reconta a história oficial para beneficiar o ponto de vista do vencedor; o esquecimento-recalcamento, que obriga a uma amnésia coletiva, tenta apagar os fatos, silenciar a história; e, finalmente, o esquecimento-apaziguamento, necessário para que os sujeitos possam seguir suas vidas, acreditar em um futuro melhor, um esquecimento imprescindível à saúde mental e psíquica dos indivíduos (OST, 1999).

Parece-nos que em nosso país vivemos constantemente sob o véu do esquecimento-recalcamento, visâo sustentada por Maria Rita Kehl (2005). Para a autora, o ressentimento é uma mescla de afetos que faz de tudo para năo ser notado, que "năo ousa dizer o seu nome" (KEHL, op. cit., p. 163), pois ressentir-se é sinal de fraqueza moral. No entanto, o indivíduo que carrega consigo um ressentimento camuflado, "dominado", é normalmente tido como puro, nobre de espírito. O ressentido pode ser descrito como um sujeito nostálgico, um vingativo năo assumido, que persiste no sofrimento enquanto responsabiliza um terceiro por sua dor, numa tentativa de afastar sua culpa inconsciente (KEHL, op. cit.).

A partir disso, pode-se afirmar que o ressentimento social é uma característica das sociedades democráticas, uma vez que nelas o Estado passa a ser considerado o avalista das promessas de igualdade, surgindo como uma figura de autoridade - quase como um pai - que deve proteger, mas também punir, os seus cidadăos. Entretanto, ante a percepçăo da injustiça, os sujeitos sentem-se frustrados e, portanto, ressentidos, transferindo suas frustraçôes para o Estado. Assim, a sociedade moderna tornou-se o local perfeito para a ascensăo do ressentimento, uma vez que, ao substituir a coerçăo externa pela consciência moral, transferiu para o indivíduo a tarefa de controle de suas açóes e acabou por ocasionar, assim, o sentimento de ressentimento quando de suas frustraçōes (KEHL, op. cit.).

Em nossa realidade, entăo, o ressentido, apesar de ver e sentir a desigualdade, năo almeja uma revoluçấo, pois se sente desconfortável com a desordem e contenta-se no papel de vítima, assumindo uma "revolta submissa". Isso porque o ressentido se identifica com o opressor ao partilharem ideias comuns. Assim, o ressentido năo quer "desalojar" o opressor do seu lugar, gostaria na realidade de ocupar o mesmo local (KEHL, op. cit.).

Nesse cenário, a insatisfaçâo se torna um ressentimento coletivo na medida em que a democracia náo garante a igualdade, como já sustentamos, mas evidencia a nocividade da injustiça. Por tudo isso, diante das promessas quebradas da democracia que năo consegue cumprir com todos os ideais por ela defendidos, e ao transferir para o 
Estado todas as responsabilidades por essa falha, acaba fazendo com que os cidadáos năo se coloquem no lugar de sujeito ativo e, portanto, culpem um terceiro pelos seus próprios fracassos.

Assim, Kehl (2005) demonstra que, em certos casos, lembrar é tăo importante quanto esquecer, na medida em que o esquecimento gera recalque e, portanto, repetiçáo. Assim, a autora se propóe a compreender qual destino poderíamos dar à memória a fim de que năo nos tornemos uma sociedade de ressentidos, nem de recalcados. Nessa lógica, um trabalho de memória com a participaçâo de um terceiro, enquanto testemunha do fato, pode desempenhar importante papel na sua superaçăo. Isso porque, ao incluir o terceiro cria-se um espaço de diálogo a partir da abertura para novas significaçóes e para a valorizaçăo da vítima, uma vez que permite que ela seja ouvida. O testemunho, a memória, permitem a inscriçăo do evento no campo simbólico e assim, a violência (o sofrimento, a dor) ao ser reproduzida pela fala (ou pelo símbolo), substitui a violência real, podendo ser assimilada e, portanto, superada.

Nessa lógica, Ost (1999) destaca que a memória é requisito indispensável para que a sociedade adquira identidade. A memória é importante, pois "nâo existe força instituinte que năo se apoie em formas instituídas" (OST, op. cit., p. 77). Como nos palimpsestos, sempre estamos construindo o novo em cima do antigo. No direito năo há criaçăo, mas adaptaçăo. Logo, "a fundaçăo é sempre ao mesmo tempo o prosseguir de uma tradiçăo, da mesma forma que a conservação ou a reiteraçâo da promessa é, inevitavelmente, reformulaçăo e transformaçăo dessa última" (OST, op. cit., p. 77). Assim, podemos enxergar o golpe de 1964 como o prosseguir de uma tradiçăo autoritária, que dá preferência à centralizaçáo do poder.

O povo brasileiro, na pressa em perdoar para năo parecer ressentido, esconde seu ressentimento na política do esquecimento. Nâo passamos nada a limpo, nâo valorizamos nossa história e nunca encontramos nossa verdadeira identidade. Preferimos assumir os estereótipos com os quais os "mais fortes" nos identificam, numa busca submissa pelo reconhecimento, numa atitude que denota nosso "complexo de inferioridade". Para mais, rejeitamos veementemente qualquer vinculaçăo com nossos fundadores, os portugueses, com os primeiros donos dessa terra, os indígenas, ou mesmo com os negros, e assim sentimo-nos órfăos. Essa orfandade simbólica nos transformou em uma sociedade que está sempre em busca de uma autoridade paterna, uma sociedade submissa (KEHL, op. cit.), o que explica o nosso anseio por presidentes com "pulso firme".

A constataçăo das debilidades da democracia brasileira, por outro lado, năo se trata de uma atitude ressentida, mas de um trabalho contra a repetiçáo produzida pelo recalque, trata-se de condiçăo para a mudança. Nessa lógica, precisamos "assumir o passado, para o melhor e para o pior, a fim de lhe dar um futuro" (OST, op. cit., p. 177). Mas, nâo basta que tenhamos memória, é preciso que saibamos lidar com ela.

Nesse sentido, precisamos pensar num "tempo metamórfico", que assuma suas responsabilidades na construçăo de um futuro possível. François Ost (op. cit.) explica que os contratos, pela cláusula do pacta sunt servanda, năo se permitem revisar. Uma promessa feita é tida como uma proposta imutável, devendo ser mantida a todo custo. No entanto, advoga o autor, é preferível que o contrato seja renegociado pelas partes a fim de que seja, de fato, cumprido, em vez de causar a sucumbência de um dos contratantes em razăo da onerosidade excessiva que dele possa resultar. Assim, o tempo, 
em vez de "engessar" o direito (ou o contrato), acaba moldando-o, atuando como aquilo que o autor chama de "tempo metamórfico" a fim de construir um futuro possível, uma promessa que se possa concretizar.

\section{PARA ONDE VAMOS? AS RECOMENDAÇÕES DA COMISSÃO NACIONAL DA VERDADE E A CHANCE DE UM RECOMEÇO COM A ADPF 320}

Parece-nos, felizmente, que ainda podemos trilhar esse caminho que passa pela memória e pelo perdáo, para que alcancemos a possibilidade de futuro promissor num "tempo metamórfico". Isso porque, motivado por uma decisăo da Corte Interamericana de Direitos Humanos, o Poder Executivo instalou, em 2011, uma comissâo da verdade no país.

A Comissâo Nacional da Verdade foi criada pela Lei n. ${ }^{\circ} 12.528 / 2011$ com a finalidade de examinar e esclarecer "as graves violaçōes de direitos humanos praticadas no período fixado no artigo oitavo do Ato das Disposiçóes Constitucionais Transitórias, a fim de efetivar o direito à memória e à verdade histórica e promover a reconciliaçăo nacional" (artigo $1 .^{\circ}$ ). Apesar de tardiamente instalada, o trabalho realizado pela CNV foi e continuará sendo de extrema importância, ainda mais em um país como o Brasil, onde a falta de uma justiça de transiçăo adequada reflete negativamente na consolidaçăo de nossa democracia.

A CNV, ao inaugurar um novo âmbito da justiça transicional no país, criou um espaço centrado nas vítimas, um local de reconhecimento, onde os mais prejudicados pela ditadura tiveram voz e, mais importante, foram ouvidos. A memória, assim, adquire aspecto relevante, tornando-se "a principal arma contra a repetiçâo" (SILVA FILHO, 2011, p. 300).

O país deve, dessa maneira, adotar e fazer seguir as recomendaçóes sugeridas pela CNV, posto que a busca pela verdade e pela memória se mostra como apenas um dos aspectos da justiça de transiçấo e năo pode, jamais, se esgotar em si mesmo, sobrepondo-se aos demais - como à justiça e a reforma das instituiçóes, por exemplo. Assim certamente o Brasil caminhará rumo à consolidaçăo de sua democracia e ao fortalecimento dos direitos humanos.

Mais recentemente, por sua vez, oSTF está tendo mais uma chance de se manifestar sobre a Lei de Anistia brasileira. ${ }^{6}$ Isso porque o Partido Socialismo e Liberdade (PSOL), em maio de 2014, interpôs a ADPF n. ${ }^{\circ}$ 320, sustentando o náo cumprimento, pelo Estado brasileiro, da decisăo proferida pela Corte IDH no Caso "Gomes Lund e Outros Vs. República Federativa do Brasil", mesmo após o transcurso de mais de três anos da prolaçâo do acórdăo. Caso a Suprema Corte venha a decidir conforme o entendimento

\footnotetext{
A Lei de Anistia foi objeto análise na ADPF n. ${ }^{\circ}$ 153, julgada em 2010 pelo STF, na qual o Conselho da OAB requeria a interpretaçăo conforme a Constituiçăo do $\S 1 .^{\circ}$ do art. $1^{\circ}$ da Lei. O pedido da OAB foi negado pela maioria dos ministros e, em funçâo disso, o julgamento dos crimes cometidos pelos agentes estatais durante a ditadura civil-militar brasileira ainda está obstado. No ano de 2011, a referida lei foi objeto de análise pela Corte Interamericana de Direitos Humanos no conhecido "Caso Araguaia". Em sua decisâo a Corte julgou que a Lei da Anistia brasileira contraria o disposto na Convençấo Americana de Direitos Humanos e determinou ao país que iniciasse as investigaçôes sobre os crimes contra a humanidade aqui cometidos no período ditatorial.
} 
da Corte IDH, um novo e importante passo será dado rumo ao fortalecimento dos direitos humanos no país.

Diante de todo o exposto, devemos ter em mente que inexistem medidas mágicas de efeitos imediatos no cenário político e econômico. Precisamos olhar para o passado para enxergar o futuro, para entendermos que nosso presente é uma repetiçáo de nossa história e para aprendermos com os nossos erros a construir um futuro melhor. Precisamos compreender que a substituiçâo de presidentes năo modifica as práticas partidárias e que uma nova constituinte ou uma intervençâo militar nâo resolverâo todos os nossos problemas. Nâo há "salvador da pátria". O nosso herói năo chegará. Será preciso que saibamos exercer nossa cidadania a fim de construirmos o novo a partir dos pressupostos constitucionais hoje estabelecidos. Essa é a tarefa necessária para manutençăo e para a consolidaçăo da democracia no país.

\section{CONSIDERAÇÕES FINAIS}

Quando pensamos em um momento marcante da história, de imediato, esse fato nos leva a outros acontecimentos que se somaram para que chegássemos onde hoje estamos. Assim, é impossível pensar a democracia no Brasil sem olharmos para trás, sem que esse exercício intelectual nos leve ao passado. Mas será que esse passado, de fato, passou? Quais as marcas de ontem, da ditadura civil-militar, na experiência democrática hoje? Essas indagaçóes compuseram a bússola que direcionou o presente trabalho. Partindo disso, buscamos fazer uma análise do período ditatorial e do processo transicional brasileiro para que possamos refletir sobre o autoritarismo que impera em nossa sociedade.

Assim como temos que enfrentar nossos medos para superá-los, também precisamos enfrentar e esclarecer os crimes cometidos no país durante a ditadura civil-militar brasileira para deixarmos para trás esse capítulo tăo nefasto de nossa história. 0 esquecimento só pode acontecer em decorrência do luto, e para que possamos viver o luto, temos que enterrar nossos cadáveres. Só conseguiremos, no entanto, sepultar esse passado quando ele for finalmente desvendado, quando sua história for enfim contada, quando a verdade for reconstruída.

No Brasil, a justiça de transiçâo anda a passos lentos: quase para. Inicialmente valorizando-se a reparaçăo pecuniária, o Estado esqueceu os demais aspectos do processo transicional, o que acabou transformando os anistiados em figuras mal vistas pela populaçâo, com frequência chamados pela mídia de caçadores de tesouros em busca da "bolsa-ditadura". Mais recentemente, com as Caravanas da Anistia e a instalaçăo e o relatório da CNV, a reparaçăo moral e a busca pela verdade e pela memória também tiveram seu espaço no processo de transiçăo brasileiro.

No entanto, a segurança pública continua atuando com extrema violência em nosso país, escolhendo os "criminosos" conforme estereótipos muito bem categorizados: se durante a ditadura o alvo era o militante, o "subversivo"; hoje é o negro, o jovem pobre da periferia. A reforma das instituiçôes é medida imperativa para que possamos mudar esse cenário.

Para mais, um aspecto da justiça transicional completamente negligenciado pelo Brasil é a responsabilizaçáo dos agentes públicos no âmbito civil, administrativo e 
penal. Apesar de o relatório da CNV ter indicado nominalmente os agentes do Estado envolvidos na perpetraçáo de crimes durante a ditadura, recomendando a apuraçáo dos fatos no âmbito judicial, a interpretaçăo que o STF dá à Lei da Anistia acaba por impedir a persecuçâo penal. A impunidade, entâo, permeia o seio de nossa democracia e transmite uma mensagem clara: no Brasil, a lei năo se aplica igualmente a todos.

Assim, quando em comparaçáo com os demais países estudados ao longo desse trabalho, fica evidente que o Brasil escolheu uma trajetória diferente, privilegiando a amnésia, a impunidade, a corrupçâo e a violência. Parece-nos que essa transiçâo política mal-acabada tem efeitos diretos na democracia vivida pelos brasileiros: o legado da ditadura pode ser visto claramente no atual cenário político que hoje vivemos, no qual impera a corrupçăo, a impunidade e a indiferença com os direitos individuais e com os princípios democráticos.

No presente trabalho, foi possível constatar que somente quando os aspectos da justiça transicional săo trabalhados em conjunto é que se obtêm progressos efetivos na valorizaçấo dos direitos humanos e no fortalecimento da democracia. Portanto, a luta pela implementaçâo do processo transicional no país é medida que se impóe. 


\section{REFERÊNCIAS BIBLIOGRÁFICAS}

ABRÂO, Paulo; TORELLY, Marcelo D. As dimensōes da justiça de transiçăo no Brasil, a eficácia da Lei de Anistia e as alternativas para a verdade e a justiça. In: PAYNE, Leigh A. (Orgs.). A anistia na era da responsabilizaçáo: o Brasil em perspectiva comparada. Brasília: Ministério da Justiça, Comissăo de Anistia; Oxford University, Latin American Centre, 2011. pp. 212-248. Disponível em: <http://www.portalmemoriasreveladas.arquivonacional.gov. br/cgi/cgilua.exe/sys/start.htm?infoid=17\&sid=4>. Acesso em: 17 maio 2015.

ANISTIA INTERNACIONAL. Informe 2014/2015: O estado dos direitos humanos no mundo. Rio de Janeiro: AI, 2015.

ARQUIDIOCESE DE SĂO PAULO. Brasil: Nunca Mais. 3. ed. Petrópolis: Vozes, 1985.

BAGGIO, Roberta Camineiro. Anistia e reconhecimento: o processo de (des)integraçăo social da transiçâo política brasileira. In: PAYNE, Leigh A.; ABRÂO, Paulo; TORELLY, Marcelo D. (Orgs.). A anistia na era da responsabilizaçáo: o Brasil em perspectiva comparada. Brasília: Ministério da Justiça, Comissâo de Anistia; Oxford University, Latin American Centre, 2011. pp. 250-277. Disponível em: <http://www.portalmemoriasreveladas.arquivonacional.gov.br/cgi/cgilua.exe/sys/start.htm?infoid=17\&sid=4>. Acesso em: 17 maio 2015.

BRASIL. Comissāo Nacional da Verdade. v. 1 Brasília: CNV, 2014.

. Lei n. ${ }^{\circ}$ 12.528, de 18 de novembro de 2011. Cria a Comissăo Nacional da Verdade no âmbito da Casa Civil da Presidência da República. Disponível em: <http://www.planalto. gov.br/ccivil_03/_ato2011-2014/2011/lei/112528.htm>. Acesso em 03 set. 2015.

CHAGAS, Carlos. A Guerra das Estrelas (1964/1984): os bastidores das sucessōes presidenciais. Porto Alegre: L\&PM, 1985.

CHAVES, Eduardo dos Santos. Mulheres de direita: a "vigília anticomunista" das gaúchas da ADFG. Revista Aedos, Porto Alegre, RS, v. 6, n. 15, pp. 34-49, jul./dez. 2014. Disponível em: <http://www.seer.ufrgs.br/index.php/aedos/article/view/50969/32259>. Acesso em: 03 jan. 2017.

CODATO, Adriano Nervo; OLIVEIRA, Marcus Roberto de. A marcha, o terço e o livro: catolicismo e açăo política na conjuntura do golpe de 1964. Revista Brasileira de História. Săo Paulo, v. 24, n. 47, p. 271-302, 2004. Disponível em: <http://www.scielo.br/pdf/rbh/ v24n47/a11v2447.pdf>. Acesso em: 03 jan. 2017.

CORDEIRO, Janaína Martins. "A naçăo que se salvou a si mesma". Entre memória e história, a campanha da mulher pela democracia (1962-1972). In: SIMPÓSIO NACIONAL DE HISTÓRIA, 24., 2007, INFORMAR CIDADE. pp. 1-9. Disponível em: <http://anais.anpuh. org/wp-content/uploads/mp/pdf/ANPUH.S24.0307.pdf>. Acesso em: 02 jan. 2017.

. Femininas e formidáveis: o público e o privado na militância política da Campanha da Mulher pela Democracia (CAMDE). Revista Gênero, Niterói, RJ, v. 8, n. 2, pp. 174-201, 2008. Disponível em: http://www.revistagenero.uff.br/index.php/revistagenero/article/view/180/118. Acesso em: 02 jan. 2017.

FAUSTO, Boris. História do Brasil. 9. ed. Săo Paulo: Editora da Universidade de Săo Paulo, 2001. 
GASPARI, Elio. A ditadura envergonhada. Săo Paulo: Companhia das Letras, 2002.

GONÇALVES, Danyelle Nilin. Os múltiplos sentidos de anistia. Revista Anistia Política e Justiça de Transiçăo, Brasília, DF, 2009, n. 01, pp. 272-95, jan.-jun. 2009. Disponível em: <http://portal.mj.gov.br/main.asp?Team=\%7B67064208-D044-437B-9F24-96E0B26CB372\%7D>. Acesso em: 07 jun. 2015.

KEHL, Maria Rita. O ressentimento camuflado da sociedade brasileira. Revista Novos Estudos CEBRAP, Săo Paulo, SP, v. 1, n. 71, pp. 163-80, mar. 2005. Disponível em: <http:// novosestudos.org.br/v1/files/uploads/contents/105/20080627_o_ressentimento_camuflado.pdf>. Acesso em: 28 nov. 2016.

O'DONNELL, Guillermo. Democracia delegativa? Revista Novos Estudos Cebrap, Săo Paulo, v. 3, n. 31, pp. 25-40, out. 1991. Disponível em: <http://novosestudos.uol.com.br/v1/files/ uploads/contents/65/20080624_democracia_delegativa.pdf>. Acesso em: 18 set. 2016.

OLSEN, Tricia D.; PAYNE, Leigh A.; REITER, Andrew G. As implicaçōes políticas dos processos de anistia. In: PAYNE, Leigh A.; ABRĀO, Paulo; TORELLY, Marcelo D. (Orgs.). A anistia na era da responsabilizaçáo: o Brasil em perspectiva comparada. Brasília: Ministério da Justiça, Comissăo de Anistia; Oxford University, Latin American Centre, 2011. pp. 542571. Disponível em: <http://www.portalmemoriasreveladas.arquivonacional.gov.br/cgi/ cgilua.exe/sys/start.htm?infoid=17\&sid=4>. Acesso em: 17 maio 2015.

OST, François. 0 tempo do direito. Traduçâo: Maria Fernanda Oliveira. Lisboa: Piaget, 1999.

PINHEIRO, Paulo Sérgio. Violência, crime e sistemas policiais em países de novas democracias. Revista Tempo Social, Sâo Paulo, v. 9, n. 1, pp. 43-52, maio 1997. Disponível em: <http://www.scielo.br/pdf/ts/v9n1/v09n1a03>. Acesso em: 28 nov. 2016.

RIDENTI, Marcelo Siqueira. As mulheres na política brasileira: os anos de chumbo. Revista Tempo Social, Săo Paulo, v. 2, n. 2, pp. 113-128, jul./dez. 1990. Disponível em: <http://www. revistas.usp.br/ts/article/view/84806>. Acesso em: 05 jul. 2016.

SILVA FILHO, José Carlos Moreira da. Justiça de transiçăo: da ditadura civil-militar ao debate justransicional. Porto Alegre: Livraria do Advogado, 2015.

. Memória e reconciliaçáo nacional: o impasse da anistia na inacabada transiçâo democrática brasileira. In: PAYNE, Leigh A.; ABRÂO, Paulo; TORELLY, Marcelo D. (Órfă.). A anistia na era da responsabilizaçăo: o Brasil em perspectiva comparada. Brasília: Ministério da Justiça, Comissấo de Anistia; Oxford University, Latin American Centre, 2011. pp. 278307. Disponível em: <http://www.portalmemoriasreveladas.arquivonacional.gov.br/cgi/ cgilua.exe/sys/start.htm?infoid=17\&sid=4>. Acesso em: 17 maio 2015.

SKIDMORE, Thomas. Uma História do Brasil. 3. ed. Săo Paulo: Paz e Terra, 2000.

SOUSA, Jessie Jane Vieira de. Anistia no Brasil: um processo político em disputa. In: PAYNE, Leigh A.; ABRÂO, Paulo; TORELLY, Marcelo D. (Orgs). A anistia na era da responsabilizaçâo: o Brasil em perspectiva comparada. Brasília: Ministério da Justiça, Comissâo de Anistia; Oxford University, Latin American Centre, 2011. pp. 188-210. Disponível em: <http://www.portalmemoriasreveladas.arquivonacional.gov.br/cgi/cgilua.exe/sys/start. htm?infoid=17\&sid=4>. Acesso em 17 maio. 2015.

STRECK, Lenio Luiz; MORAIS, José Luis Bolzan de. Ciência política e teoria do Estado. 7. ed. Porto Alegre: Livraria do Advogado, 2010. 
TOURAINE, Alain. O que é a democracia? Traduçăo: Guilherme Joăo de Freitas Ferreira. 2. ed. Petrópolis: Vozes, 1996.

VAN ZYL, Paul. Promovendo a justiça transicional em sociedades pós-conflito. In: REÁTEGUI, Félix. (Org.). Justiça de Transiçâo: manual para a América Latina. Brasília: Ministério da Justiça, Comissăo de Anistia; Nova Iorque, Centro Internacional para Justiça de Transiçăo, 2011. pp. 47-71.

Disponível em: <http://www.dhnet.org.br/verdade/resistencia/a_pdf/manual justica_ transicao_america_latina.pdf $>$. Acesso em: 11 jun. 2015.

ZAVERUCHA, Jorge. Relaçôes civil-militares: o legado autoritário da Constituiçâo brasileira de 1988. In: SAFATLE, Vladimir; TELES, Edson (Orgs.). 0 que resta da ditadura: a exceçâo brasileira. Sâo Paulo: Boitempo, 2010. pp. 41-76. 